\title{
Pengaruh Pemberian Air Susu Ibu dan Fototerapi terhadap Ikterus Neonatorum di Ruang Perinatologi RSUD Pasaman Barat
}

\author{
Yulia M. Nur ${ }^{1}$ Elnita Rahmi' Eliza $^{3}$ \\ ${ }^{1-3}$ STIKes Nan Tongga, Lubuk Alung \\ Email: yuliamnur17@gmail.com
}

Submitted : 02/10/2020

Accepted: 06/01/2021

Published: $06 / 03 / 2021$

\begin{abstract}
Neonatal jaundice is a common problem in the care of normal newborns. West Pasaman Regional Hospital data states that in 2018 there were 41 cases of neonatal jaundice out of 369 deliveries. The research objective was to determine the effect of exclusive breastfeeding and phototherapy on the incidence of neonatal jaundice. The research method is retrospective, namely conducting research on past events. The research was conducted at RSUD Pasaman Barat with a population of 20 people. Sampling was done by total sampling technique, so that the sample size is 20 people. Data collection was carried out by means of observation at the West Pasaman Regional Hospital. The approach used is cross sectional, namely independent and dependent data collection is done at the same time. The data that has been collected is then processed manually and analyzed by computerized univariate and bivariate analysis. This type of research is descriptive with a cross sectional design. The study population was all babies in West Pasaman Regional Hospital with a total of 41 people, the sample size was determined by the total sampling so that the sample was 41 people. The data was collected by means of a documentation study using a checklist. Data processing was carried out by univariate computerization. The results showed that as many as 13 respondents $(31.7 \%)$ were breast-fed, $63.4 \%$ were carried out with phototherapy and $24.4 \%$ of respondents had neonatal jaundice. Based on the bivariate analysis obtained p value 0.049 (Breastfeeding) and 0.001 (Phototherapy). The results of the Chi Square test, it can be concluded that there is an effect of breastfeeding and phototherapy on the incidence of neonatal jaundice.
\end{abstract}

Keywords : ASI, perinalogy room, phototherapy, neonatoral jaundice

Abstrak
Ikterus neonatorum merupakan masalah yang sering dijumpai pada perawatan bayi baru lahir normal. Data RSUD Pasaman Barat menyatakan bahwa tahun 2018 terdapat 41 kasus Ikterus Neonatorum dari 369 persalinan. Tujuan penelitian adalah untuk mengetahui pengaruh ASI Eksklusif dan Fototerapi terhadap Kejadian Ikterus Neonatorum. Metode penelitian adalah retrospektif yaitu melakukan penelitian terhadap kejadian yang telah lampau. Jumlah populasi 20 orang, pengambilan sampel dilakukan dengan teknik total sampling, sehingga besar sampel adalah 20 orang. Pengumpulan data dilakukan dengan cara observasi di RSUD Pasaman Barat. Pendekatan yang digunakan adalah cross sectional yaitu pengambilan data independen dan dependen dilakukan pada saat yang bersamaan. Data yang telah dikumpulkan kemudian diolah secara manual dan dianalisis secara komputerisasi dengan analisa univariat dan bivariat. Jenis penelitian ini adalah deskriptif dengan desain ccross sectional. Populasi penelitian adalah semua bayi di RSUD Pasaman Barat dengan jumlah 41 orang, besar sampel ditentukan total sampling sehingga sampel adalah 41 orang. Pengumpulan data dilakukan dengan cara studi dokumentasi dengan menggunakan daftar ceklist. Pengolahan data dilakukan secara univariat secara komputerisasi. Hasil penelitian menunjukkan bahwa sebanyak 13 responden $(31,7 \%)$ dilakukan pemberian ASI, sebanyak 63,4\% dilaksanakan fototerapi dan Sebanyak 24,4\% responden mengalami ikterus neonatorum. Berdasarkan analisis bivariat didapatkan $p$ value 0,049 (Pemberian ASI) dan 0,001 (Fototerapi). Berdasarkan hasil uji Chi Square disimpulkan terdapat pengaruh pemberian ASI dan fototerapi terhadap kejadian ikterus neonatorum.

Kata Kunci : ASI, fototerapi, ikterus neonatorum, ruang perinalogi 


\section{PENDAHULUAN}

Ikterus neonatorum merupakan masalah yang sering dijumpai pada perawatan bayi baru lahir normal, khususnya di Asia, yaitu munculnya warna kuning pada kulit dan sklera karena terjadinya hiperbilirubinemia sampai bayi usia 72 - 120 jam dan akan kembali normal setelah 7 - 10 hari (Lin, Tsao, Hsieh, Chen, \& Chou, 2008), (Pediatrics, 2004), (Smithermen, Stark, \& Bhutani, 2006) dalam (Nursanti, 2011). Ikterus pada bayi baru lahir pada minggu pertama terjadi pada $60 \%$ bayi cukup bulan dan $80 \%$ bayi kurang bulan. Hal ini adalah keadaan yang fisiologis. Walaupun demikian, sebagian bayi akan mengalami ikterus yang berat sehingga memerlukan pemeriksaan dan tata laksana yang benar untuk mencegah kesakitan dan kematian (Suradi \& Letupeirissa, 2013).

Ketika bayi berada di dalam kandungan, sel darah ini akan dikeluarkan melalui uri (plasenta) dan diuraikan oleh hati ibu. Bila kadar bilirubin darah melebihi $2 \mathrm{mg} \%$, maka ikterus akan terlihat namun pada neonatus ikterus masih belum terlihat meskipun kadar bilirubin darah sudah melampui $5 \mathrm{mg} \%$.

Ikterus terjadi karena peninggian kadar bilirubin indirek (unconjugated) dan atau kadar bilirubin direk (conjugated). Bilirubin sendiri adalah anion organik yang berwarna orange dengan berat molekul 584.Asal mula bilirubin dibuat daripada heme yang merupakan gabungan protoporfirin dan besi. Ikterus dibedakan menjadi 3 tipe ikterus fisiologi, ikterus patologik, kern ikterus. Ikterus fisiologik adalah ikterus yang timbul pada hari kedua dan hari ketiga yang tidak mempunyai dasar patologik, kadarnya tidak melewati kadar yang membahayakan atau yang mempunyai potensi menjadi kern ikterus dan tidak menyebabkan suatu morbiditas pada bayi. Ikterus patologi adalah ikterus yang mempunyai dasar patologi atau kadar bilirubinnya mencapai suatu nilai yang disebut hiperbilirubinemia (Marmi, 2012).

Berbagai cara telah digunakan untuk mengelola bayi baru lahir dengan hiperbilirubinemia indirek. Strategi tersebut termasuk pencegahan, penggunaan farmakologi, fototerapi dan transfusi tukar. American Academy of Pediatrics tahun 2004 mengeluarkan strategi praktis dalam pencegahan dan penanganan hiperbilirubinemia bayi baru lahir $(<35$ minggu atau lebih) dengan tujuan untuk menurunkan insidensi dari neonatal hiperbilirubinemia berat dan ensefalopati bilirubin serta meminimalkan risiko yang tidak menguntungkan seperti kecemasan ibu, berkurangnya breastfeeding atau terapi yang tidak diperlukan. Pencegahan dititik beratkan pada pemberian minum sesegera mungkin, sering menyusui untuk menurunkan shunt enterohepatik, menunjang kestabilan bakteri flora normal, dan merangsang aktifitas usus halus (Sukadi, 2012).

Ikterus akibat ASI merupakan unconjugated hiperbilirubinemia yang mencapai puncaknya terlambat ( biasanya menjelang hari ke 6-14). Dapat dibedakan dari penyebab lain dengan reduksi kadar bilirubin yang cepat bila disubstitusi dengan susu formula selama 1-2 hari. Hal ini untuk membedakan ikterus pada bayi yang disusui ASI selam minggu pertama kehidupan. Sebagian bahan yang terkandung dalam ASI (beta glucoronidase)akan memecah bilirubin menjadi bentuk yang larut dalam lemak, sehingga bilirubin indirek akan meningkat, dan kemudian akan diresorbsi oleh usus. Bayi yang mendapat ASI bila dibandingkan dengan bayi yang mendapat susu formula, mempunyai kadar bilirubin yang lebih tinggi berkaitan dengan penurunan asupan pada beberapa hari pertama kehidupan. Pengobatannya bukan dengan menghentikan pemberian ASI 
melainkan dengan meningkatkan frekuensi pemberian (Marmi, 2012).

Angka Kematian Bayi (AKB) merupakan salah satu aspek yang sangat penting dalam mendeskripsikan tingkat pembangunan manusia di sebuah negara dari sisi kesehatan masyarakatnya. Angka Kematian Bayi di negara-negara ASEAN seperti Singapura 3 per 1.000 kelahiran hidup, Brunei Darussalam 8 per 1.000 kelahiran hidup, Malaysia 10 per 1.000 kelahiran hidup,Vietnam 18 per 1.000 kelahiran hidup, dan Thailand 20 per 1.000 kelahiran hidup sedangkan AKB di Indonesia masih cukup tinggi yakni sebesar 34 per 1.000 kelahiran hidup yang masih jauh di bawah target MDGs 23 per 1.000 kelahiran hidup (Sihombing, 2012).

Angka Kematian Bayi di Sumatera Barat Tahun 2015 sebesar 27 per 1000 kelahiran, masih lebih rendah dibandingkan dengan AKB Indonesia pada tahun yang sama (Kemenkes RI, 2016). AKABA di Kabupaten Pasaman Barat dari tahun 2011 sampai dengan 2014 terjadi penurunan, namun terjadi peningkatan lagi pada tahun 2015 yaitu dengan jumlah kematian balita 108 jiwa atau 14 per 1.000 kelahiran hidup dan angka tersebut masih statis pada tahun 2016 dengan jumlah kematian balita sebanyak 118 jiwa. Dibandingkan dengan target SDGs yaitu sebesar 25/1.000 kelahiran hidup maka AKB di Kabupaten Pasaman Barat tahun 2016 sudah cukup baik karena tidak melampaui target SDGs.

Menurut WHO dalam laporannya menjelaskan bahwa asfiksia neonatus merupakan urutan pertama penyebab kematian neonatus di negara berkembang pada tahun yaitu sebesar $21,1 \%$, setelah itu pneumonia $(19,0 \%)$ dan tetanus neonatorum $(14,1 \%)$ dan ikterus neonatorum $5,4 \%$, dan lain-lain (Kompas, 2016). Data WHO menyatakan bahwa di Amerika Serikat, sebanyak $65 \%$ bayi baru lahir menderita ikterus dalam minggu pertama kehidupannya. Di Malaysia, hasil survei pada tahun 2014 di rumah sakit pemerintah dan pusat kesehatan di bawah Departemen Kesehatan mendapatkan $35 \%$ bayi baru lahir menderita ikterus dalam minggu pertama kehidupannya.Di Indonesia, insiden ikterus neonatorum pada bayi cukup bulan di beberapa RS pendidikan antara lain RSCM, RS Dr. Sardjito, RS Dr. Soetomo, RS Dr. Kariadi bervariasi dari 13,7\% hingga $85 \%$. Data RSUP Dr. M.Djamil Padang menyatakan bahwa pada tahun 2015 tercatat $12,6 \%$ bayi dirawat karena ikterus (Handayani, 2016).

Di Kabupaten Pasaman Barat pada tahun 2017 terdapat 8.336 ibu melahirkan. Data RSUD Pasaman Barat tercatat 39 bayi yang mengalami ikterus neonatorum selama tahun 2016 dari 361 persalinan, sedangkan pada RSI Yarsi Ibnu Sina Simpang Empat terdapat 203 bayi yang mengalami ikterus neonatorum dari 1.104 bayi yang lahir di RSI Yarsi Simpang Empat. Berdasarkan data rekam medik tahun 2018 diketahui 20 bayi mengalami ikterus neonatorum selama Januari - November 2018. Berdasarkan data diketahui bahwa pada umumnya bayi yang mengalami ikterus neonatorum diberikan terapi ASI dan fototerapi (Data Rekam Medik RSUD dan RSI Yarsi Simpang Empat, 2018).

Optimisasi pemberian ASI pada periode perinatal adalah penting, jika kadar bilirubin meningkat, dianjurkan untuk mendukung ibu agar lebih sering menyusui dengan interval 2 jam dan tidak memberikan makanan tambahan, atau setidaknya $8-10 x$ per 24 jam. Ada hubungan yang jelas antara frekuensi menyusui dengan penurunan insidensi hiperbilirubinemia. Pemberian yang sering mungkin tidak akan meningkatkan intake tetapi akan meningkatkan peristaltik dan frekuensi $\mathrm{BAB}$ sehingga meningkatkan ekskresi bilirubin. Pilihan terapi dalam menangani kasus bayi dengan hiperbilirubinemia untuk menurunkan kadar bilirubin tidak terkonjugasi antara lain fototerapi (Martiza, 2012). 
Berdasarkan latar belakang di atas, peneliti tertarik melakukan penelitian tentang "Pengaruh Kolostrum dan Fototerapi terhadap Ikterus Neonatorum di Ruang Perinatologi RSUD Pasaman Barat Tahun 2018 “

\section{METODE PENELITIAN}

Penelitian ini bersifat Retrospektif yaitu melakukan penelitian terhadap kejadian yang telah terjadi di masa lampau. Desain penelitian yaitu Cross Sectional, yaitu penelitian yang menggambarkan hubungan antara variabel indendepen dengan variabel dependen, dimana pengambilan data secara bersamaan pada waktu yang sama pula (Notoadmojo, 2009).

Populasi pada penelitian ini adalah semua bayi yang mengalami iketrus neonatorum pada tahun 2019 sebanyak 41 orang. Tekhnik pengambilan sampel dalam penelitian ini adalah total Sampling, yaitu suatu teknik pengambilan sampel dimana seluruh anggota populasi dijadikan responden penelitian. Besar sampel adalah 20 orang.

Data yang dikumpulkan pada penelitian ini adalah data sekunder. Data sekunder yaitu data dari pihak kedua, berupa data kejadian ikterus neonatorum, kolostrum dan fototerapi di RSUD Pasaman Barat serta kajian literature yang berhubungan dengan penelitian ini dari berbagai kepustakaan.

Data yang terkumpul diolah dan dianalisa dengan metode deskriptif kuantitatif, menggunakan tabel distribusi frekuensi dan dikelompokkan sesuai sub variabel yang diteliti, yaitu : kejadian ikterus neonatorum, kolostrum dan fototerapi. Analisis data ini menggunakan system komputerisasi.

Analisa bivariat dimaksudkan untuk melihat hubungan antara variabel independen dengan variabel dependen yaitu kejadian ikterus neonatorum, kolostrum dan fototerapi.Untuk menguji data tersebut digunakan software SPSS dengan Uji ChiSquare.

\section{HASIL DAN PEMBAHASAN Analisa Univariat}

Analisa univariat adalah analisa masingmasing variable independen yang bertujuan untuk menjelaskan dan mendeskripsikan karakteristik masing-masing variabel yang diteliti.Analisis univariat bertujuan untuk mengetahui distribusi frekuensi responden masing-masing variabel dan dapat dilihat pada uraian di bawah ini :

\section{Pemberian ASI}

Hasil penelitian sehubungan dengan pemberian ASI di Ruang Perinatologi RSUD Pasaman Barat dapat dilihat pada tabel berikut :

Tabel 1. Distribusi Frekuensi Responden Berdasarkan Pemberian ASI Di Ruang Perinatologi

\begin{tabular}{lcc}
\hline \multicolumn{1}{c}{ Pemberian ASI } & $\mathrm{f}$ & $\%$ \\
\hline ASI & 13 & 31,7 \\
Tidak ASI & 28 & 68,7 \\
Jumlah & 41 & 100 \\
\hline
\end{tabular}

Berdasarkan tabel 1 diketahui bahwa dari 41 responden hanya 13 orang $(31,7 \%)$ yang diberikan ASI, sedangkan 28 lainnya $(68,7 \%)$ tidak diberikan ASI.

Hasil penelitian menunjukkan bahwa dari 41 responden hanya 13 orang $(31,7 \%)$ yang diberikan ASI, sedangkan 28 lainnya $(68,7 \%)$ tidak diberikan ASI. Pemberian ASI dilakukan pada bayi yang tidak diberikan fototerapi ataupun pada bayi yang kadar bilirubinnya $5 \mathrm{mg} \%$.

Air Susu Ibu adalah cairan yang keluar dari payudara ibu yang bermanfaat bagi bayi untuk pertumbuhan dan perkembangannya (Utami, 2015). Protein yang terdapat didalam ASI merupakan protein yang berkualitas tinggi karena mengandung asam amino esensial yang sangat penting untuk proses tumbuh kembang bayi, dan sangat menguntungkan bayi karena mudah dicerna, mengingat sistem enzim bayi baru lahir belum begitu 
sempurna. Protein dalam ASI mempunyai peranan sebagai anti infeksi.

Hasil penelitian ini lebih tinggi dibandingkan dengan penelitian yang dilakukan oleh Martiza (2012) dengan hasil $31,9 \%$ responden menyatakan bahwa tidak diberikan ASI. Hasil penelitian ini sebanding dengan penelitian yang dilakukan oleh Apriliyan (2017) yang mendapatkan hasil 40,4\% responden yang tidak memberikan ASI eksklusif. Hasil penelitian ini sebanding dengan penelitian yang dilakukan oleh Tridininlestari (2017) yang mendapatkan hasil $54,1 \%$ responden yang tidak memberikan ASI eksklusif. Hasil penelitian ini sebanding dengan penelitian yang dilakukan oleh Aprilia (2016) yang mendapatkan hasil 60,2\% responden yang tidak memberikan ASI eksklusif.

Bayi yang mendapat ASI eksklusif dapat mengalami ikterus. Ikterus ini disebabkan oleh produksi ASI yang belum banyak pada hari hari pertama. Bayi mengalami kekurangan asupan makanan sehingga bilirubin direk yang sudah mencapai usus tidak terikat oleh makanan dan tidak dikeluarkan melalui anus bersama makanan. Di dalam usus, bilirubin direk ini diubah menjadi bilirubin indirek yang akan diserap kembali ke dalam darah dan mengakibatkan peningkatan sirkulasi enterohepatik. Keadaan ini tidak memerlukan pengobatan dan jangan diberi air putih atau air gula. Untuk mengurangi terjadinya ikterus dini perlu tindakan sebagai berikut : bayi dalam waktu 30 menit diletakkan ke dada ibunya selama 3060 menit, posisi dan perlekatan bayi pada payudara harus benar, berikan kolostrum karena dapat membantu untuk membersihkan mekonium dengan segera (Suradi, dkk, 2013).

Mekonium yang mengandung bilirubin tinggi bila tidak segera dikeluarkan, bilirubinnya dapat diabsorbsi kembali sehingga meningkatkan kadar bilirubin dalam darah, bayi disusukan sesuai kemauannya tetapi paling kurang 8 kali sehari, jangan diberikan air putih, air gula atau apapun lainnya sebelum ASI keluar karena akan mengurangi asupan susu, monitor kecukupan produksi ASI dengan melihat buang air kecil bayi paling kurang 6-7 kali sehari dan buang air besar paling kurang 3-4 kali sehari (Suradi, dkk, 2013).

Menurut asumsi peneliti, pemberian ASI harus dilaksanakan terutama bagi yang masih berusia 0-6 bulan untuk mencapai ASI eksklusif. Pemberian ASI harus dilaksanakansesering mungkin sebanyak yang diinginkan bayi. Rendahnya cakupan ASI eksklusif ini disebabkan oleh berbagai faktor seperti puting susu ibu tidak ada, produksi ASI kurang, bayi tidak mau menyusui, ibu mengalami baby blues, dan lain-lain. Berbegai metode tradisional maupun obat-obatan modern dilakukan untuk meningkatkan produksi ASI.

\section{Fototerapi}

Hasil penelitian yang berhubungan dengan pelaksanaan fototerapi di Ruang Perinatologi dapat dilihat pada tabel 2 berikut :

\section{Tabel .2 Distribusi Frekuensi Responden} Berdasarkan Fototerapi Di Ruang Perinatologi

\begin{tabular}{ccc}
\hline Fototerapi & $\mathrm{f}$ & $\%$ \\
\hline Fototerapi & 26 & 63,4 \\
Tidak fototerapi & 15 & 36,6 \\
Jumlah & 41 & 100 \\
\hline
\end{tabular}

Berdasarkan tabel 2 diketahui bahwa dari 41 responden, sebanyak 26 responden $(63,4 \%)$ dilaksanakan fototerapi, sedangkan 15 lainnya $(36,6 \%)$ tidak difototerapi. Hasil penelitian diketahui bahwa dari 41 responden, sebanyak 26 responden $(63,4 \%)$ dilaksanakan fototerapi, sedangkan 15 lainnya $(36,6 \%)$ tidak difototerapi. Pelaksanaan fototerapi tergantung dari kadar bilirubin pada bayi. Bayi yang difototerapi jika memiliki kadar bilirubin > $5 \mathrm{mg} \%$ atau dengan indikasi daerah kepala, leher dan badan bagian atas sudah terlihat kuning. 
Fototerapi rumah sakit merupakan tindakan yang efektif untuk mencegah kadar Total Bilirubin Serum (TSB) meningkat. Uji klinis telah divalidasi kemanjuran fototerapi dalam mengurangi hiperbilirubinemia tak terkonjugasi yang berlebihan, dan implementasinya telah secara drastis membatasi penggunaan transfusi tukar (Bhutani, 2011). Penelitian menunjukkan bahwa ketika fototerapi belum dilakukan, $36 \%$ bayi dengan berat kelahiran kurang dari 1500 gram memerlukan transfusi tukar (Newman, et al , 2009).

Mekanisme Kerja Fototerapi Bilirubin tidak larut dalam air. Cara kerja terapi sinar adalah dengan mengubah bilirubin menjadi bentuk yang larut dalam air untuk dieksresikan melalui empedu atau urin. Ketika bilirubin mengabsorbsi cahaya, terjadi reaksi fotokimia yaitu isomerisasi. Juga terdapat konversi ireversibel menjadi isomer kimia lainnya bernama lumirubin yang dengan cepat dibersihkan dari plasma melalui empedu. Bilirubin adalah produk terbanyak degradasi bilirubin akibat terapi sinar pada manusia. Sejumlah kecil bilirubin plasma tak terkonjugasi diubah oleh cahaya menjadi dipyrole yang diekskresikan lewat urin. Fotoisomer bilirubin lebih polar dibandingkan bentuk asalnya dan secara langsung bisa dieksreksikan melalui empedu. Hanya produk foto oksidan saja yang bisa diekskresikan lewat urin (Sastroasmoro, dkk, 2004).

Hasil penelitian ini lebih tinggi dibandingkan dengan penelitian Rina Mulita (2011) yang mendapatkan hasil $55,9 \%$ responden mengalami fototerapi. Lintang (2014) dengan judul penelitian Hubungan Jenis Persalinan dengan Kejadian Ikterus Neonatorum di RSUD Dr. Moewardi Surakarta Tahun 2014 mendapatkan hasil bahwa pada tahun 2014 terdapat $33,8 \%$ bai ikterus diobati dengan fototerapi. Hasil penelitian ini lebih tinggi dibandingkan dengan penelitian
Harisnamurti (2018) yang mendapatkan hasil $80,4 \%$ responden mengalami fototerapi.

Menurut asumsi peneliti, fototerapi harus dilakukan pada bayi yang level ikterus neonatorumnya sudah parah. Hal ini dilaksanakan agar dapat mengurangi kejadian ikterus pada bayi dan meminimalisir terjadinya dampak negatif yang bahkan dapat berakibat pada kematian. Pelaksanaan fototerapi dapat diberikan oleh perawat jika mendapatkan persetujuan oleh orang tua bayi.

\section{Ikterus Neonatorum}

Hasil penelitian yang berhubungan dengan kejadian Ikterus Neonatorum di Ruang Perinatologi RSUD Pasaman Barat dapat dilihat pada tabel.3

Tabel .3 Distribusi Frekuensi Responden Berdasarkan Ikterus Neonatorum di Ruang Perinatologi

\begin{tabular}{ccc}
\hline Ikterus Neonatorum & $\mathrm{f}$ & $\%$ \\
\hline Tidak Ikterus & 31 & 75,6 \\
Ikterus neonatorum & 10 & 24,4 \\
Jumlah & 41 & 100 \\
\hline
\end{tabular}

Berdasarkan penelitian diketahui bahwa dari 41 responden, sebanyak 31 orang $(75,6 \%)$ sudah tidak mengalami Ikterus Neonatorum dan 10 orang $(24,4 \%)$ masih mengalami ikterus. Bayi yang mengalami ikterus neonatorum berasal dari berbagai daerah yang ada di Pasaman Barat, baik yang lahir di RSUD Pasaman Barat ataupun pasien rujukan dari puskesmas atau dari BPS (Bidan Praktek Swasta).

Ikterus adalah warna kuning pada kulit, konjungtiva dan selaput akibat penumpukan bilirubin. Sedangkan hiperbilirubinemia adalah ikterus dengan konsentrasi bilirubin serum yang menjurus ke arah terjadinya kernikterus atau ensefalopati bilirubin bila kadar bilirubin yang tidak dikendalikan(Wiknjosastro, 2009).

Hasil penelitian ini lebih rendah dibandingkan dengan penelitian yang 
dilakukan oleh Martiza (2012) dengan hasil $29,2 \%$ responden memiliki bayi ikterus neonatorum. Hasil penelitian Aida (2012) dalam judul penelitian Hubungan Berat Badan Lahir Rendah dengan Kejadian Ikterus di RSUD Gresik menyatakan bahwa $12,4 \%$ responden melahirkan bayi ikterus neonatorum. Hasil penelitian ini lebih tinggi dibandingkan dengan penelitian Harisnamurti (2018) yang mendapatkan hasil $23,4 \%$ responden mengalami fototerapi

Menurut asumsi peneliti, ikterus neonatorum yang dialami oleh responden disebabkan karena bayi kurang banyak mendapatkan asupan ASI, bayi mengalami BBLR, ibu yang preeklamsia, dan ketuban pecah dini. Selain itu, ikterus neonatorum juga ditemukan pada bayi yang mengalami asfiksia. Bayi ikterus neonatorum harus mendapatkan penanganan lebih lanjut agar

Tabel .4 Hubungan Pemberian ASI dengan kterus Neonatorum di Ruang Perinatologi

\begin{tabular}{|c|c|c|c|c|c|c|c|c|}
\hline \multirow{3}{*}{ Pemberian ASI } & \multicolumn{4}{|c|}{ Ikterus Neonatorum } & \multicolumn{2}{|c|}{ Total } & \multirow{3}{*}{$\begin{array}{c}\text { P value } \\
0,49\end{array}$} & \multirow{3}{*}{$\begin{array}{c}\text { OR } \\
0,194\end{array}$} \\
\hline & \multicolumn{2}{|c|}{ Ikterus } & \multicolumn{2}{|c|}{ Tidak Ikterus } & & & & \\
\hline & $\mathrm{n}$ & $\%$ & $\mathrm{~N}$ & $\%$ & $\mathrm{~N}$ & $\%$ & & \\
\hline ASI & 4 & 14,3 & 7 & 53,8 & 13 & 100 & & \\
\hline Tidak ASI & 6 & 46,2 & 24 & 85,7 & 28 & 100 & & \\
\hline Jumlah & 10 & 24,4 & 31 & 75,6 & 97 & 100 & & \\
\hline
\end{tabular}

Dari tabel 4 diatas terlihat bahwa responden dari 13 responden yang diberikan ASI, sebanyak 6 responden $(46,2 \%)$ masih ikterus neonatorum dan 7 responden $(53,8 \%)$ tidak mengalami ikterus. Dari uji statistik didapatkan nilai $p$ $=0,027(\mathrm{p}<0,05), \quad$ sehingga dapat disimpulkan bahwa terdapat pengaruh pemberian ASI dengan kejadian ikterus neonatorum. Nilai OR 0,194 sehingga dapat disimpulkan bahwa pengaruh ASI terhadap pengurangan ikterus sangat kecil yaitu hanya 0,194 .

ASI merupakan makanan terbaik dan almiah untuk bayi. Air susu Ibu (ASI) adalah makanan terbaik bayi pada awal kehidupan, hal ini tidak hanya karena ASI mengandung cukup zat gizi tetapi karena ASI mengandung zat imunologik yang kadar bilirubin kembali berada dalam batas yang normal dan tidak terjadi kerusakan yang lebih membahayakan jiwa bayi dan tumbuh kembangnya.

\section{Analisa Bivariat}

Analisa bivariat merupakan analisa yang dilakukan terhadap dua variabel dalam hal ini, analisa bivariat bertujuan untuk mengetahui hubungan variable independen dengan variabel dependen. Analisa bivariat dilakukan secara komputerisasi dengan menggunakan uji Chi Square. Hasil analisa bivariat penelitian ini sebagai berikut :

\section{Hubungan Pemberian ASI dengan Kejadian Ikterus Neonatorum}

Hubungan antara pemberian ASI dengan kejadian ikterus neonatorum dapat pada tabel berikut : menyusui di negara berkembang telah berhasil menyelamatkan sekitar 1,5 juta bayi pertahun, atas dasar tersebut WHO merekomendasikan hanya untuk memberikan ASI sampai bayi berusia 4 sampai 5 bulan (Depkes RI, 2008).

Hasil penelitian menyatakan bahwa dari 13 responden yang diberikan ASI, sebanyak 6 responden $(46,2 \%)$ masih ikterus neonatorum dan 7 responden $(53,8 \%)$ tidak mengalami ikterus. Dari uji statistik didapatkan nilai $p=0,027(\mathrm{p}<$ 0,05), sehingga dapat disimpulkan bahwa terdapat pengaruh pemberian ASI dengan kejadian ikterus neonatorum. Nilai OR 0,194 sehingga dapat disimpulkan bahwa pengaruh ASI terhadap pengurangan ikterus sangat kecil yaitu hanya 0,194 . 
Proses menyusui dilanjutkan delapan kali atau lebih dalam sehari dan ibu dianjurkan menyusui secara teratur dalam 24 jam. Pada proses inisiasi menyusu dini terdapat fase bayi menjilat-jilat kulit ibu sehingga memudahkan flora normal kulit ibu masuk ke pencernaan bayi. Bakteri berfungsi untuk pengubahan bilirubin serta aktifitas enzim glukoronidase pada usus bayi. Apabila bakteri tidak terdapat dalam usus maka terjadi peningkatan hidrolisis bilirubin terkonjugasi menjadi bilirubin tak terkonjugasi dan masuk ke siklus enterohepatik. Kejadian ikterik neonatorum berhubungan dengan peningkatan siklus enterohepatik yang disebabkan tertumpuknya bilirubin pada gangguan pasase mekonium (Bobak, 2005). Bayi yang mendapat kolostrum berperan sebagai laksatif alami (pencahar) yang membantu mendorong mekonium keluar dari tubuh. Kolostrum mulai diproduksi pada akhir kehamilan dan tetap bertahan hingga empat hari setelah kelahiran. Bilirubin yang dikeluarkan melalui mekonium menurunkan kadar bilirubin serum yang menjadi penyebab ikterik (Bobak, 2005).

Hasil penelitian ini sebanding dengan penelitian yang dilakukan oleh Martiza (2012) menyatakan bahwa terdapat hubungan bermakna antara pemberian ASI dengan pengurangan kejadian bayi ikterus neonatorum. Hasil penelitian ini sebanding dengan penelitian yang dilakukan oleh Tridininlestari (2017) yang mendapatkan hasil terdapat hubungan bermakna antara pemberian ASI dengan pengurangan kejadian bayi ikterus neonatorum. Hasil penelitian ini sebanding dengan penelitian yang dilakukan oleh Aprilia (2016) yang mendapatkan hasil terdapat hubungan bermakna antara pemberian ASI dengan pengurangan kejadian bayi ikterus neonatorum OR 4,6.

3. Hubungan Fototerapi dengan Ikterus Neonatorum

Hubungan fototerapi dengan kejadian ikterus neonatorum di ruang perinatologi dapat dilihat pada tabel berikut Tabel 5 Hubungan Fototerapi dengan Ikterus Neonatorum di Ruang Perinatologi

\begin{tabular}{|c|c|c|c|c|c|c|c|c|}
\hline \multirow[t]{3}{*}{ Fototerapi } & \multicolumn{4}{|c|}{ Ikterus Neonatorum } & \multicolumn{2}{|c|}{ Total } & \multirow{3}{*}{$\begin{array}{l}\text { value } \\
0,01\end{array}$} & \multirow{3}{*}{$\begin{array}{r}\text { OR } \\
13,714\end{array}$} \\
\hline & \multicolumn{2}{|c|}{ Ikterus } & \multicolumn{2}{|c|}{ Tidak Ikterus } & & & & \\
\hline & $\mathrm{n}$ & $\%$ & $\mathrm{n}$ & $\%$ & $\mathrm{n}$ & $\%$ & & \\
\hline Fototerapi & 2 & 7,7 & 24 & 92,3 & 26 & 100 & & \\
\hline Tidak fototerapi & 8 & 53,3 & 7 & 46,7 & 15 & 100 & & \\
\hline Jumlah & 10 & 24,4 & 31 & 75,6 & 41 & 100 & & \\
\hline
\end{tabular}

Berdasarkan tabel 5 diatas terlihat bahwa dari 26 responden yang diberikan fototerapi, sebanyak 24 responden $(92,3 \%)$ tidak mengalami ikterus dan 2 responen $(7,7 \%)$ mengalami ikterus. Dari uji statistik didapatkan nilai $p=0,009$. Artinya, $p<$ 0,01 , sehingga dapat disimpulkan bahwa terdapat pengaruh yang bermakna antara fototerapi dengan kejadian ikterus neonatorum.

Hasil penelitian menyatakan bahwa dari 26 responden yang diberikan fototerapi, sebanyak 24 responden $(92,3 \%)$ tidak mengalami ikterus dan 2 responen $(7,7 \%)$ mengalami ikterus. Dari uji statistik didapatkan nilai $p=0,009$. Artinya, $p<$ 0,01 , sehingga dapat disimpulkan bahwa terdapat pengaruh yang bermakna antara fototerapi dengan kejadian ikterus neonatorum. Nilai OR 13,714, sehingga dapat disimpulkan bahwa responden yang difototerapi mengalami peluang 13,7 kali tidak ikterus neonatorum dibandingkan yang tidak mengalami fototerapi.

Bila kadar bilirubin serum meningkat sangat cepat atau mencapai kadar kritis, dianjurkan untuk menggunakan fototerapi dosis ganda atau intensif, teknik ini melibatkan dengan menggunakan lampu overhead konvensional sementara itu bayi berbaring dalam selimut fiberoptik. Warna 
kulit bayi tidak mempengaruhi efisiensi pemberian fototerapi. Hasil terbaik terjadi dalam 24 sampai 48 jam pertama fototerapi (Wong, 2017). Fototerapi intensif adalah fototerapi dengan menggunakan sinar bluegreen spectrum (panjang gelombang 430-490 nm) dengan kekuatan paling kurang $30 \mathrm{uW} / \mathrm{cm} 2$ (diperiksa dengan radio meter, atau diperkirakan dengan menempatkan bayi langsung di bawah sumber sinar dan kulit bayi yang terpajan lebih luas. Bila konsentrasi bilirubin tidak menurun atau cenderung naik pada bayi bayi yang mendapat fototerapi intensif, kemungkinan besar terjadi proses hemolisis (Kosim, dkk, 2012).

Penelitian ini sejalan dengan penelitian yang dilakukan oleh Martiza (2012) yang menyatakan bahwa terdapat hubungan yang bermakna antara fototerapi dengan kejadian ikterus neonatorum. Penelitian yang dilakukan oleh Lintang (2014) dengan judul penelitian Hubungan Jenis Persalinan dengan Kejadian Ikterus Neonatorum di RSUD Dr. Moewardi Surakarta Tahun 2014,menyatakan bahwa ada hubungan yang bermakna antara fototerapi dengan kejadian ikterus neonatorum di RSUD Dr. Moewardi Surakarta. Hasil penelitian ini lebih tinggi dibandingkan dengan penelitian Harisnamurti (2018) yang mendapatkan hasil ada hubungan yang bermakna antara fototerapi dengan kejadian ikterus neonatorum.

Nilai OR 13,714, sehingga dapat disimpulkan bahwa responden yang difototerapi mengalami peluang 13,7 kali tidak ikterus neonatorum dibandingkan yang tidak mengalami fototerapi.

Menurut Bhutani (2011) untuk mengurangi efek samping fototerapi maka dokter dan rumah sakit harus memastikan bahwa perangkat fototerapi digunakan harus sepenuhnya menerangi luas permukaan tubuh pasien, memiliki tingkat radiasi dari $\geq 30 \mu \mathrm{W} \quad \mathrm{cm}-2 \quad \mathrm{~nm} 1$ (dikonfirmasi dengan akurasi dengan radiometer spektral yang sesuai) selama waveband sekitar 460-490 nm, dan diimplementasikan secara tepat waktu.

Menurut Wong (2009) untuk mengefektifkan fototerapi, kulit bayi harus terpajan penuh terhadap sumber cahaya dengan jumlah yang adekuat. Bila kadar bilirubin serum meningkat sangat cepat atau mencapai kadar kritis, dianjurkan untuk menggunakan fototerapi dosis ganda atau intensif, teknik ini dengan menggunakan lampu overhead konvensional sementara itu bayi berbaring dalam selimut fiberoptik. Warna kulit bayi tidak mempengaruhi efisiensi pemberian fototerapi. Hasil terbaik terjadi dalam 24 sampai 48 jam pertama fototerapi.

Penelitian ini sejalan dengan pendapat yang dikemukakan oleh Hendryawati (2011) yang mengatakan bahwa secara klinis (kramer) pemberian fototerapi atau day light dapat menurunkan derajat ikterik pada bayi ikterik. Penelitian ini sejalan dengan penelitian yang dilakukan oleh Lasmani (2000) yang memberikan hasil penelitian faktor resiko terjadinya hiperbilirubinemia pada berat badan lahir cukup (BBLC) yang secara statistik bermakna adalah keterlambatan pemberian ASI, efektifitas menetek dan asfiksia neonatorum menit ke-1.

Dan juga penelitian yang dilakukan oleh Triasih (2003), dengan hasil penelitian terdapat hubungan antara kadar bilirubin total 24 jam pertama dengan hari kelima yang dapat digunakan untuk memprediksi terjadinya hiperbilirubunemia pada bayi cukup bulan pada minggu pertama kehidupan. Penelitian ini juga mendukung penelitian yang dilakukan oleh Pratita (2010) yang memberikan hasil pemberian fototerapi efektif dalam menurunkan kadar bilirubin dengan jarak sinar lebih dekat ke neonatus lebih efektif dalam menurunkan kadar bilirubin pada bayi-bayi dengan hiperbilirubinemia. 


\section{SIMPULAN}

Adapun kesimpulan dari penelitian ini adalah sebagai berikut : Sebanyak 13 responden $(31,7 \%)$ dilakukan pemberian ASI di Ruang Perinatologi RSUD Pasaman Barat tahun 2019. Sebanyak 63,4\% dilaksanakan fototerapi di Ruang Perinatologi RSUD Pasaman Barat tahun 2019. Sebanyak 24,4\% responden mengalami ikterus neonatorum di Ruang Perinatologi RSUD Pasaman Barat tahun 2019. Terdapat pengaruh pemberian ASI terhadap kejadian ikterus neonatorum di Ruang Perinatologi RSUD Pasaman Barat tahun 2019. Terdapat pengaruh fototerapi terhadap kejadian ikterus neonatorum di Ruang Perinatologi RSUD Pasaman Barat tahun 2019.

\section{SARAN}

Disarankan untuk peneliti selanjutnya dapat mengembangkan konsep penelitian dengan mengkaji ataupun melakukan penelitian terhadap faktor-faktor lain yang berhubungan dengan ikterus neonatorum.

\section{UCAPAN TERIMAKASIH}

Ucapan terima kasih penulis aturkan kepada semua pihak yang telah membantu sehingga penelitian ini bisa diselesaikan dengan baik dan sesuai dengan apa yang diharapkan. Selain itu ucapan penulis sampikan kepada Bapak/Ibu pimpinan dan segenap staf STIKes Nan Tongga Lubuk Alung.

\section{DAFTAR PUSTAKA}

Aida, R,2012. Hubungan Berat Badan Lahir Rendah dengan Kejadian Ikterus di RSUD Gresik. Jurnal Kesehatan Vol. 3 Tahun 2012

Apriliyan, A.S, 2017. Hubungan ASI Eksklusif dengan Kejadian Ikterus Neonatorum. Jurnal Skill Fitokimia.

Bobak, I.M., Lowdermilk, D.L., \& jensen, M.D., 2005. Buku Ajar Keperawatan
Maternitas. Alih bahasa : Wijayarini MA., \& Anugrah PL Jakarta : Penerbit Buku Kedokteran EGC.

Budiasih, Kun Sri, 2009. Handbook Ibu Menyusui. Bandung : Hayati Qualita

Bhutani, V. 2011. -Phototherapy to Prevent Severe Neonatal Hyperbilirubinemia in the Newborn Infant 35 or More Weeks of Gestationl. Journal of the American Academy of Pediatrics, Vol. 128, No. 4, PP e 1046 - e 1052.

Faiqah, S, 2015. Hubungan Usia Gestasi dan Jenis Persalinan dengan Kadar Bilirubinemia di RSUP Nusa Tenggara Barat. KTI Kebidanan

Handayani, 2016. Skenario Ikterus Jilid 4. www.perinatologi.com diakses 2 Januari 2019

Harisnamurti, 2018. Pengaruh Fototerapi terhadap Kadar Bilirubin pada Bayi Ikterus Neonatorum. Jurnal Kesehatan

Hindryawati, Wiwin. 2011. Media Sehat ( PPNI ). Edisi 35., Semarang : Arfmedia Grup

Lasmani, Patricia S. 2000. Faktor Resiko Hiperbilirubinemia pada Bayi Baru Lahir dengan Berat Badan Lahir Cukup di RSUP DR. SARDJITO YOGYAKARTA. Skripsi. PSIK Universitas Gajah Mada Yogyakarta

Lintang, R. 2014. Hubungan Jenis Persalinan dengan Kejadian Ikterus Neonatorum di RSUD Dr. Moewardi Surakarta Tahun 2014. Skripsi Kedokteran.

Kompas, 2016. Angka Kematian Ibu, Bayi dan Balita di Indonesia. Diakses 25 Desember 2018

Maisels, M.J. 2008. Neonatal Jaundice. Amsterdam : Harwood Academic Publisher : 177-203

.Manuaba IBG. 2008. Memahami Kesehatan Reproduksi Wanita. Jakarta: EGC. 


\section{Penuntun Diskusi \\ Obstetri Dan Ginekologi Untuk Mahasiswa Kedokteran. Jakarta: EGC 2010. Ilmu Kebidanan, Penyakit Kandungan, dan KB. Jakarta : EGC \\ Mansjoer, Arief, 2012. Kapita Selekta Kedokteran. Jakarta : PT. Gramedia}

Marmi, S. S. T., \& Raharjo, K., 2012. Asuhan Neonatus, Bayi, Balita, dan Anak Prasekolah. Yogyakarta : CV. Pustaka Pelajar.

Martiza, Iesje. (2012). Buku Ajar Gastroenterologi-Hepatologi. Jakarta : CV. Badan Penerbit IDAI.

Maryunani, A., Nurhayati. (2008). Asuhan Bayi Baru Lahir Normal. Jakarta : Trans Info Media

Mochtar, 2011. Sinopsis Obstetri Jilid I. Jakarta : EGC , 2013. Sinopsis Obstetri Jilid I Edisi VII. Jakarta : EGC

Moeslichan, Surjono, A., Suradi. R., Rahardjani, K. B.,Usman. A., Rinawati, et al., 2012. Tatalaksana Ikterus Neonatorum.

Newman, T., Kuzniewicz, M., Liljestrand, dkk. 2009. Number Needed to Treat With Phototherapy According to American Academy of Pediatrics Guidelines. Journal of the American Academy of Pediatrics, Vol. 123, No. 5, PP 1352-1359.

Notoatmodjo, S. 2009. Metodologi Penelitian Kesehatan. Jakarta : Rineka Cipta

Poverawati, 2009. Bahan Ajar Kebidanan : Gizi pada Balita. Yogyakarta: Nuhamedika

Purwanti, Sri, 2014. ASI Eksklusif dan Ibu Pekerja. Jakarta : Yayasan Bina Pustaka

Rina Mulita, 2011. Faktor-Faktor yang Berhubungan dengan Kejadian Ikterus Neonatorum di RSU Muhammadiya PKU
Roesli Utami, 2015. Inisiasi Menyusui Dini Plus ASI Eksklusif (Cetakan I). Jakarta : Pustaka Bunda.

RSUD Pasaman Barat, 2019. Laporan Tahunan 2018

RS Yarsi, 2019. Data Rekam Medik Tahun 2018

Sihombing, Vivian. 2012. Asuhan Neonatus Bayi dan Anak Balita. Jakarta : CV. Salemba Medika.

Sukadi, A. 2012. Buku Ajar Neonatologi. Jakarta : CV. Badan Penerbit IDAI.

Suradi, Abdurachman, Ali Usman, Syarief Hidayat Efendi. 2012. Ikterus Neonatorum. Perinatologi. Bandung. Bagian/SMF Ilmu Kesehatan Anak FKUP/RSHS.

Suradi, R, dan D. Letupeirissa, 2013. Buku Bedah ASI

IDAI. https://www.idai.or.id/artikel/klinik/a si/air-susu-ibu-dan-ikterus. Diakses 1 September 2020.

Tridininlestari, 2017. Hubungan Pemberian ASI Eksklusif dengan Kejadian ISPA pada Bayi 6-24 Bulan. Jurnal Kesehatan Vol 5 Tahun 2018

WHO, 2014. Management of hyperbilirubinemia in the new born infant 35 or more weeks of gestation. Diakses tanggal : 2 Januari 2016. From : http://www.aapublication.org.

Wiknjosastro, 2009. Buku Ajar Kebidanan : Ilmu Kandungan Jakarta : Yayasan Bina Pustaka , 2014. Ilmu Kandungan. Jakarta : Yayasan Bina Pustaka

Wong, D.L., \& Hockenberry, M.J, (2003). Nursing care of infant and children. 7th edition. Philadhelphia : Mosby

Wong, D.L. 2009. Buku Ajar Keperawatan Pediatrik. Diterjemahkan oleh Agus S., Neti J., Kuncoro., Vol. 1. Edisi 6. Cetakan 1., Jakarta : Penerbit Buku Kedokteran EGC 